I Federal University of Rio de Janeiro (UFRJ), Postgraduate

Program in Sociology and Anthropology (PPGSA), Rio de Janeiro, RJ, Brazil

veronicatoste@gmail.com

Veronica Toste Daflon'

\title{
FORMS OF SYSTEMATIZATON OF THE SOCIOLOGY OF RACE RELATIONS IN BRAZIL
}

\section{INTRODUCTION}

During their training as researchers and teachers, the academics who work with race, racism and racial discrimination tend to absorb a canonical history of the interpretations of race relations in Brazil. This history usually narrates the absorption of scientific racism at the end of the nineteenth century and goes on to describe the emergence within the social sciences of the idea that Brazil was characterized by harmonious and democratic race relations. Finally, it relates the break with this vision and the construction of the consensus around the existence of patterns of racial discrimination and inequality in the country, as well as the urgent need to investigate them.

The acquisition of this species of 'map' of the field is without doubt obligatory for anyone intending to work in the area. Despite the problems, the chronology has enabled those entering the field to build common reference points, mediate their academic dialogues and assume a constructive approach in their own research. Sometimes, though, it can take on an overly mechanical and gradualist form, suggesting a highly accumulative notion of science or a reading guided by a logic of discovery, which loses sight of historicity and the innumerable nuances of the huge literature on race relations in Brazil.

The present article systemizes the contributions of authors who have sought to produce more wide-ranging syntheses of the interpretive movements produced in the field, shedding light on different aspects of this literature in 
the process. Here I highlight George Fredrickson (200I), Peter Wade (I997), Edward Telles (2004) and Antonio Sérgio Guimarães (I999a) for the way in which they avail themselves of the vast academic output on race relations in Brazil in order to detect the different research approaches and theoretical frameworks mobilized by the authors and schools over time.

The text first presents the most usual form of describing the history of the academic production in race relations in Brazil. Next it summarizes the way in which the four authors, based on distinct theoretical and disciplinary affiliations, interrogate this history. In the final section it explores some recent studies that embody some of the insights obtained by these authors in their reviews of the field of race relations in Brazil.

\section{A NARRATIVE OF THE INTERPRETATIONS}

Presentation of the huge academic literature on race relations in Brazil tends to follow more or less the same narrative: the surveys begin by describing how the scientific racism of European origin was absorbed by Brazilian intellectuals like Nina Rodrigues, Sílvio Romero and Oliveira Vianna. This set of authors associated black and mixed-race populations with degeneracy, inferiority and incompatibility with national progress. In response to this supposed problem, they discussed the viability and future of an admittedly miscegenated nation like Brazil's. Next, authors surveying this literature underline the rupture produced by Gilberto Freyre, who, seeking to interpret race relations in Brazil, shifts from the idea of 'race' to the idea of culture. Generally speaking, the claim tends to be that while Freyre sought to supplant the racist theses of the previous generation, he also painted an overly positive or even romantic picture of race relations in the country. Particular emphasis is given to the considerable influence of Casa-grande \& senzala, as well as the way in which Freyre, in rejecting the myth of 'race,' collaborated to replace it within another: the myth of racial democracy. Despite recognizing the cruelty and violence of slavery, Freyre disseminated positivized ideas of miscegenation, of the dilution of racial boundaries, along with the theses of Lusotropicalism and Brazilian racial harmony (Ortiz, I985; Munanga, I999; Skidmore, 1976).

Subsequently, the influence of the Freyrean paradigm on a generation of Brazilianist researchers is usually highlighted - academics like Donald Pierson, Marvin Harris and Charles Wagley - along with the hegemony of the thesis of 'racial democracy' in the field of race relations. Emphasized next is the importance of the studies developed under the UNESCO Project, which collected ample evidence of the existence of racial prejudice in Brazil in different regions of the country and initiated the rupture in relation to the earlier view. Here special attention is paid to Florestan Fernandes (1965; 1972), who associated miscegenation, until then seen as a panacea for Brazil's problems, with a racist campaign of whitening the ultimate objective of which was the disappearance of the black 
population. Prominence is given to Fernandes for interpreting racial prejudice as a way for the white elite to maintain its patrimonial privileges and its monopoly over the social positions of status (Ortiz, I985; Munanga, I999).

Next mention is made of the analyses of Carlos Hasenbalg and Nelson do Valle Silva, who produced important evidence of racial discrimination in Brazil based on advanced statistical models, deepening the critique of the Freyrean paradigm and definitively undermining the credibility of the imaginary of 'racial democracy' in the academic environment. The Hasenbalg-Fernandes dialogue also gains considerable prominence, given the differences in their treatment of the relationship between racism and capitalism. The generation that succeeded Hasenbalg and Silva generally refuted the idea that Brazil is founded on harmonious and democratic race relations, and a dedication to investigating patterns of racial discrimination and inequality in the country (Theodoro, 2008).

We should not lose sight of the fact that this chronological narrative is a contested intellectual history. A recent example is the rediscovery of the work of Virgínia Leone Bicudo, a black woman whose research into racial attitudes in São Paulo became forgotten and shelved for years. Bicudo's pioneering work explored questions of identity, racial awareness and strategies of social mobility, taking the combination of race and class as explanatory axes (Maio, 2010). Another example is the growing importance attributed to the work of Guerreiro Ramos for introducing the theme of 'whiteness' into the Brazilian debate many decades before the 'white' identity began to be systematically interrogated by the social sciences (Sovik, 2009). It is also worth recalling the relatively delayed recognition of Manoel Bomfim, an intellectual who rejected racialist explanations for Brazil's 'ills' long before Gilberto Freyre and, in so doing, directly confronted the country's social and political questions during the first years of the Republic (Ortiz, I985). Other researchers have also sought to foreground the contributions of black intellectuals like Abdias Nascimento, especially in his intellectual exchanges with Guerreiro Ramos and Florestan Fernandes, and Lélia González, for calling attention in pioneering fashion to relations between race and gender in Brazil (Chaloub \& Pinto, 2016). Attention is also focused on the interlocutions between academia and black organizations, and how they mutually influence each other (Guimarães, I999a). In this way, the canon has become the target of diverse disputes over who the more representative authors are, what their relative weight is within the field and the structure assumed by this field per se.

\section{INTERPRETATIONS OF THE INTERPRETATIONS}

The approach summarized here may frequently suggest a logic of accumulation and/or 'discovery,' notions highly criticized by the philosophy of science. In order to get round this problem, it is important to elucidate how movements within the field, which touch on questions of method and theory, and outside 
of it, which concern its interaction with social and political events and with ideas originating beyond the organizational boundaries of the area, affect the production of knowledge on racism as a phenomenon in Brazilian society. In the next topic, therefore, I shall examine works that share the feature of interrogating the literature on race relations in Brazil from other angles and perspectives in order to show how this academic production can be divided up in different ways.

\section{GEORGE FREDRICKSON AND THE HISTORICAL COMPARISON OF BRAZIL AND THE UNITED STATES}

Explicit and implicit comparisons between Brazil and the United States predominate in practically the entire literature relating to race relations in Brazil. Indeed Gilberto Freyre's own optimistic analysis of the relations between races in the country was based in large part on the contrast with the racial situation in the United States. In turn, Freyre's work also influenced a more general historiographic trend. Freyre not only produced a national interpretation, he also represented Brazil at international level, projecting an image that would influence comparative research between the USA and Brazil over the decades (Costa Pinto, 2009). It is precisely the forms of comparing and contrasting the United States and Brazil that comprise the focal point of the reading of the literature on race relations in the two countries made by historian George Fredrickson.

\section{Culturalism and contrast}

Fredrickson (200I) points out that comparative research on race has passed through diverse phases. Until the mid-I96os, it was informed by a strongly culturalist perspective, which sought patterns of race relations in the 'Catholic,' 'Protestant,' 'patrimonialist' or 'liberal' past of the colonies that had employed slave labour in order to explain later developments and patterns of race relations in the present. A prime example of this work is the historical comparison produced by Frank Tannembaum (1946) on Brazil and the United States in the book Slave and citizen, in which the author argues that the 'Catholic humanism' of the Portuguese colonizer had been responsible for a more harmonious, mild and democratic pattern of race relations than that of the Protestant English colonies. Both inside and outside the field of historiography, Tannembaum introduced the tendency to make inferences about the present on the basis of an examination of the slavery regime of the past, temporally leaping over everything that occurred in between (Cooper, I996). This approach presumed that certain cultural repertoires were not only capable of explaining the form assumed by slavery in the colonies, but also served to describe tendencies encountered in the present. Such a viewpoint was very widespread in historical studies of race (Fredrickson, 200I). 


\section{Slavery, demographics and 'patterns'}

Over time, the explanations concerning slavery shifted away from the cultural to other factors, such as, for instance, the demographic. Rather than expressing 'cultural' inclinations of the colonizers, the different forms assumed by race relations under slavery regimes were seen to have a more direct relation with the sizes of black and white populations in the colonies. The very existence of a social stratum of mulatos in Brazil and other Latin American countries is thus attributed to forms of colonial management on situations where there was a scarcity of white workers to perform tasks of intermediary and remunerated status (Fredrickson, 200I).

The demographic imbalance between men and women also appeared as an explanation: while in the United States there was a pattern of white families migrating with a relative demographic equilibrium between the sexes, the fact that the colonization of Brazil had been a mostly male undertaking had led to higher levels of miscegenation and greater tolerance of interracial relationships (Fredrickson, 200I; Degler, I97 I). It is worth remembering that, contrary to what Fredrickson suggests, this approach was not only utilized in the comparison of Brazil and the United States. Charles Boxer (2002), studying the Portuguese Colonial Empire, made ample use of this perspective. As well as rebutting the Freyrean theses that Portuguese colonization had not been discriminatory, he showed that more rigid or flexible mechanisms of exclusion were employed to administer colonial populations as convenient and according to their racial composition. Continuing on from Boxer's work, the Portuguese historian Francisco Bethencourt (2013) currently adopts the demographic approach to discuss race and colonialism in diverse national cases.

\section{Theories of modernization}

Fredrickson (200I) notes that in the I970s, despite a relative decline in the culturalist approach, many historiographic studies worked with the notion of 'racial patterns' inherited from the past. New historical research projects undertaken in the United States began, however, to modify this tendency. Joel Williamson (1984), for example, demonstrated that the binary racial system of the United States, as well as the one-drop rule, was not rigorously established until the end of the nineteenth century and does not, therefore, date back to the slavery system. The one-drop rule, so widely mentioned as a kind of 'inverse rule' to the Brazilian form of classification, did not become a legal norm until the Jim Crow era at the turn of the century.

Due to this and other debates on racial classification, the tendency today is to avoid thinking of 'racial patterns.' In the field of history, there is vehement criticism of the premise that during the slavery and colonial period immutable 'patterns of race relations were formed that lasted until the present. 
Also according to Fredrickson (200I), other studies from this period, though focused on the present, shared the idea that urbanization and industrialization processes, and the emergence of a competitive social order, tended to lead to a decline in the importance of the ideas of race and racism. Mythologized by teleological notions of development and modernization, many historians, the author argues, contaminated their research with future projections, supposing that all capitalist societies were in the process of extinguishing 'premodern' and 'irrational' forms of racial discrimination and inequality.

\section{Macro-historical sociology}

One of the major turning points in the historiographic production on race comes from researchers who began to work in closer detail on the twentieth century, ceasing to presume a historical linearity in relation to previous centuries, and to interpret history from an institutionalist perspective (Fredrickson, 200 I; Hanchard \& Chung, 2004; Cooper, I996). It was no longer a question of looking for 'patterns' of race relations in the slavery past or presuming the existence of a phased, cumulative and linear tendency of race relations, but of investigating in what ways the conflicts between business owners and the State, socioeconomic factors, and configurations of interest groups could be analysed in order to comprehend forms of discrimination and legal segregation established over the course of the twentieth century (Fredrickson, 200I).

Historical analysis thus assumed a more contemporary profile. As well as shifting away from culturalist readings of the past and its connections with the present, this literature also tends to reject modernization theories (Fredrickson, 200I). A good example here is Anthony Marx's work. In Making race and nation, Marx (I998) seeks to understand why the United States and South Africa imposed forms of legal segregation on their black populations, while Brazil did not. In analysing segregationist polices from a historical and comparative perspective attentive to processes of nation-building, the author suggests that racial exclusion institutionalized by the State, as well the control of the rights of citizenship and the consequent crystallization of racial divisions, served strategic purposes in the United States and South Africa. The conflict between north and south of the United States and between the British and Afrikaners in South Africa created divisions among the white populations. In order to re-establish unity and mitigate the conflicts, the elites in power encouraged white nationalism and reinforced racial distinctions vis-à-vis the black population, utilizing race as an element in national construction and internal pacification. Brazil, for its part, had followed a distinct trajectory since, in the absence of conflict between the white elites, faced less pressure to reconcile them through racial domination. Hence the State could invest in an ideology of racial democracy, at the same time as it maintained and frequently deepened informal practices of exclusion and discrimination. 
The logic of the contrast that guided the studies between I 930 and I 970 today has given way to the logic of comparison. Hence, while in the I 970 s the comparativist historian Carl Degler (I97I) established strong contrasts between Brazil and the United States with regard to their systems of racial classification, Reginald Daniel (2006) in the 2000s affirmed that Brazil and the United States were on a 'path to convergence': while the former was heading towards a more bipolar system of racial classification, the latter was becoming more multiracial and valorising miscegenation.

What we learn from the analysis of Fredrickson (200I) is that historiography has become increasingly critical of the logic of a 'contrast' between Brazil and the United States. It avoids making temporal leaps to explain 'patterns' and is cautious in its treatment of culture as a determinant. For this list of authors, it is evident that determined cultural patterns of racial classification and interaction also influence historical development. This cannot simply be presumed, however: it needs to be demonstrated.

\section{PETER WADE: RACIAL RELATIONS IN BRAZIL AND THE PARADIGMS OF THE SOCIAL SCIENCES}

An alternative form of organising the interpretations of race relations in Brazil was produced by Peter Wade. An anthropologist and specialist in race relations in Latin America, Wade (I997) grouped the Brazilian literature on race relations around different theoretical paradigms of the social sciences: functionalist, Marxist-structural and postmodern. His classification makes visible theories that were circulating and mobilized in the interpretations of Brazil at different moments, and tells us how they demarcated certain boundaries and, at the same time, enabled different aspects of race relations to be explored. However, his bibliographic review needs to be treated with some caution since it tends to privilege either the literature produced by Brazilianists or the publications available in English. This leads to his work overlooking certain nuances and the originality of Brazilian authors, both given much more emphasis by a commentator like Antonio Sérgio Guimarães (I999a).

\section{The functionalist paradigm}

Wade (I997) claims that between I930 and I950, functionalism set a general trend in the social sciences, namely the tendency to consider the black population a 'problem' in the nation-building processes of the United States and Latin America. Turning to ideas of integration, assimilation and the production of integrated wholes, this phase had, Wade asserts, the following characteristics: (I) the idea that racial and ethnic identities are destined to vanish; (2) the very strong association of indigenous and black populations with the past, primitivism, traditionalism, slavery and archaic modes of culture, life and production; (3) the tendency to take racial and ethnic identities as objective and concrete, given facts that could simply be observed, rather than social constructions. 
In fact, part of the Brazilian literature on race had the initial idea that black people embodied particular archaic or primitive forms of life. These ideas are reflected in works focused on Afro-Brazilian culture written by authors like Nina Rodrigues, Arthur Ramos and Gilberto Freyre. This tendency, however, is not generalizable to all the authors from this period. Guimarães (201 2, I999a) shows, for example, how black intellectuals and politicians in the r940s and 50 s were harsh critics of the worship of an atavistic blackness identified in these authors.

Peter Wade (I997) also presents a highly selective and partial view of the UNESCO project, taking aspects of the works of Donald Pierson and Marvin Harris to be representative of this entire academic output. For Wade, the general view of the UNESCO project was that the United States with its 'caste' system was the home of 'real' race relations and racism by which other societies should be measured. This explained the fact that the form in which race operated in Brazil had been rendered invisible. Closer attention to this production, however, refutes this notion: Oracy Nogueira, Virgínia Leone Bicudo, Thales de Azevedo and Luiz Aguiar de Costa Pinto, among others, were highly emphatic about the presence of racial prejudice in Brazil and highlighted its particular characteristics, which distinguished race relations in Brazil from those that occurred in the United States.

Still in the context of the UNESCO studies, Wade (2002) emphasizes that Florestan Fernandes was the author who talked the most explicitly about racism. Wade, though, criticizes him strongly, stressing that the relation between race and capitalism in his work demonstrates an adherence to modernization theory. Wade summarizes his ideas as follows: for Florestan, the freed black population had been placed at the lowest level of the occupational ladder due to their lack of education and the skills needed for the capitalist labour market - or the 'competitive social order.' Although the migration of European workers exacerbated this situation, removing the black population from the labour market and causing its marginality, immigration had expanded the competitive order, bringing modernization and, over time, the gradual incorporation of black workers. In Wade's view, Fernandes imagined a gradual change towards a democratic capitalism in which racial discrimination no longer had a function. In Wade's reading (I997), Fernandes thus reproduced a vision of race associated with modernization theory that was similar to the view held by some of the historians studied by Fredrickson and that hindered the perception of connections between racism and the present time. As we shall see later, Guimarães (I999a) produces a radically different reading of the work and legacy of Florestan Fernandes for the field of race relations in Brazil.

\section{The Marxist-structural paradigm}

Wade (I997) describes the work produced in the I970s as deeply influenced by Marxism. As a result, in the field of race relations, inequality and mechanisms 
of exploitation became an increasingly important focus of inquiry, shifting the gaze away from small and narrower domains of interethnic relations. The author also emphasizes that works like those of Fredrick Barth on groups and their boundaries show how ethnic identity is flexible, contextual and constructed, producing shockwaves in established forms of investigating groups and identities. Barth criticized the conception of ethnic groups as entities that perpetuate themselves through a set repertoire of cultural attributes over time, establishing the bases for thinking of identities as situational. Although Barth's approach had not been directly incorporated into the field of race relations in Brazil something that we only see more recently; for example, in works like those of José Maurício Arruti (2006) and Jan French (2009) - Wade (I997) is correct to point out that the main impact of his work stems from the fact that ethnic identities cease to be seen as doomed to vanish under 'modernization': if they are flexible and connected to inequality, then there is no force intrinsic to capitalist development that would lead them to disappear.

For Wade (1997), the influence of Marxism and political economy made themselves particularly felt in the works of Hasenbalg and Silva. Hasenbalg argued that racism was not an anachronistic relic of slavery, but an active force in capitalist society, functioning in favour of the white population in competitive situations. Wade alleges, however, that these two authors ignored the situational nature of racial categorization and took the survey categories as objective data. Wade's reading here seems mistaken and somewhat ungenerous. Silva (I995), for instance, wrote specific works on the subject and both he and Hasenbalg always insisted that their statistical analyses of discrimination and inequality did not allow inferences to be made about how people experienced discrimination and identities, but only about how inequality operates along racial lines (Silva, Hasenbalg \& Lima, I999).

\section{The 'postmodern' paradigm}

Wade (I997) signals that in the I980s and gos the main influences on the Brazilian literature were postmodernism and relativism. As well as the contributions of Derrida, which substantially changed how identity and difference were viewed, Foucault comprises another essential reference point. Critiquing the notion that ideology is 'false consciousness' and postulating that discourses and modes of representation construct social realities, Foucault called attention to the fact that people are more than simply constrained by discourse: they are constituted by it, reproducing discourse as truth through their own thought and behaviour. This comprises the 'linguistic turn' in social theory. The ideas of 'decentring' and 'multiple identities' of authors like Stuart Hall (apud Wade, I997), for their part, pose in other terms the question that had occupied Brazilian academics for a long time: was race or class the most important dimension of the country's inequalities? By accepting the idea of 'multiple identities,' class 
and race, as well as other dimensions like gender, came to coexist and represent non-mutually exclusive axes of the constitution of inequalities and identities.

The period described by Wade (I997) also involved the rejection of totalizing explanations and a critique of the metanarratives of western thought and teleological ideas of progress, accompanied by feminist and postcolonial critiques of the authority of male and western thought. Politically, this signified a certain decline in class politics and a rise in political mobilization around issues of sexuality and gender. In organizing themselves along these axes and criticizing the silence of the human sciences concerning these categories, the social movements had significant impacts on forms of thinking about race and ethnicity (Wade, I997). With the theoretical and political emphasis on the dimensions of discourse and representation, culture becomes one of the main focal points and arenas of dispute in academic production and political reflection. Now, however, culture is not seen as something that groups simply 'possess,' but something lived and open to different readings (Wade, I997).

It is patent in the description proposed by Wade (I997) that the 'postmodern vogue' introduces ambivalence insofar as academia begins to directly interrogate the construction of identity through complex relational and representational processes, and, at the same time, engage in a closer dialogue with social movements that are very often in the process of constructing their identities. As a result, academic works that avoid reifying and essentializing identities and racial classifications frequently enter into direct conflict with the political selfrepresentation of those social movements that affirm their collective origins, ancestralities, essences and characteristics as part of an invention of tradition.

\section{EDWARD TELLES AND THE TWO GENERATIONS: THE FIRST AND SECOND GENERATION OF RESEARCHERS}

A very different attempt to organize the literature on race relations in Brazil is provided by Edward Telles (2004). Rather than thinking of chronologies, turns or paradigms, Telles, a sociologist specialized in race relations in Latin America, organized the literature on race relations into two major 'generations' of researchers. Despite cautioning that the production does not always follow a linear chronological order and that there are mixtures of ideas and changes of position, he argues that the social science literature can be grouped into two currents.

The first is the generation that supported the thesis of racial democracy, according to which Brazil was, uniquely, a society that included the black population. Telles associates this generation with the legacy of Gilberto Freyre, for whom miscegenation was a positive aspect of Brazilian culture, and the existing racial inequality was a residue of a past of slavery, with a tendency to disappear given the absence of active mechanisms of discrimination. Telles (2004) includes in this generation the Brazilianists Donald Pierson, Marvin Harris, Charles Wagley and Carl Degler. It is also from this generation that the idea emerged that 
the hierarchy of social relations in Brazil is determined by class prejudice - not racial prejudice - particularly in the writings of Harris and Wagley.

The second generation, for its part, had challenged the theory of racial democracy by arguing that Brazil was characterized by severe forms of racial exclusion. Telles emphasizes that, under the leadership of Florestan Fernandes, the researchers from the UNESCO project gathered ample evidence of racial prejudice in the country, and their joint efforts would lead to the questioning of the notion of 'racial democracy.' Telles (2004) summarizes this disagreement in the following terms: according to the first school of thought, there was little or no racism in Brazil; for the second, by contrast, racism was widespread.

\section{Ideology or methodology?}

Telles (2004) links these two generations to different methodologies: for him, rather than necessarily expressing a determined normative or ideological vision of the researchers, the dispute between the two generations of scholars of race relations can be attributed to different research approaches. According to the author, the first generation had focused on sociability and social relations primarily between persons of the same social class, while the second generation emphasized inequality and discrimination between persons of different classes.

Thus the first generation had backed the idea of racial democracy not necessarily because they were hostages to the Freyrean or Piersonian paradigm, but because they focused on the sociability of white and black individuals from the lower classes, among whom there are indeed close relations of kinship, friendship, neighbourliness and marriage. After all, as Telles (2004: 7) explains, "for Pierson, a student of the emerging Chicago School of Sociology, interracial segregation and marriage were appropriate indicators of the adaptability or integration of minority groups into society." The second generation, in turn, by emphasizing the relations between people of different social classes, encountered more rigid and segregated patterns of race relations. This trend, Telles argues, was even more accentuated in the works of Carlos Hasenbalg and Nelson do Valle, which, despite producing statistical studies of interracial unions and racial classification, did not dialogue with authors from the first generation. Based on this typology, Telles (2004) affirms that one generation examined and described 'horizontal' relations while the other examined 'vertical' relations.

By emphasizing the structural axis of inequalities based on a predominantly statistical approach, Telles writes, without paying equal attention to the sphere of sociabilities, the second generation found it difficult to produce logical inferences and reconcile the apparently contradictory facts that Brazil possesses less rigid boundaries between black and white populations than the United States and, nonetheless, the country is capable of sustaining severe forms of racial inequality. His objective, therefore, is to integrate these observations into a single model capable of explaining why in Brazil forms of inclusion 
and exclusion of black people both coexist: the former, ambiguous, operated in the horizontal relations between black and white members of the lower classes; the latter, rigid, governed the vertical relations between these individuals from different classes.

Telles's thesis of 'horizontal' and 'vertical' relations today comprises one of the most promising avenues for interpreting race relations in Brazil, given that it pays close attention to the intersections between race and class in the country. In relation to his interpretation of the literature on race relations, however, although the diagnosis is good, it clearly tends to flatten the terrain too much: in search of a 'final synthesis,' Telles (2004) organizes the bibliography according to determined emphases and selections that lend support to his argument. This leads to the loss of some nuances and a large zone of ambiguity found in diverse studies, especially those developed between the I950s and 70s. These differences, more or less subtle, have been better explored by Antonio Sérgio Guimarães. Even so, Telles successfully produced one of the most critical bibliographic reviews of an evolutionist vision of science. In his description, there is no movement of one particular perspective being superseded by another that is more 'advanced.' On the contrary, Telles suggests that much remains to be recuperated and used from the studies developed in the I930s and 40 , given their capacity to elucidate determined aspects of race relations in Brazil that the more recent production has tended to ignore.

\section{ANTONIO SÉRGIO GUIMARÃES AND THE BRAZILIAN LITERATURE ON RACE RELATIONS}

\section{Baianos and paulistas?}

It is by exploring more or less the same question as Telles concerning the different interpretations of race relations that Guimarães (I999a) organizes the literature on race relations. Instead of dividing the literature into 'generations,' as Telles does, he turns to the classic theme of the supposed regional traditions of studies of race relations - the Bahia school versus the São Paulo school, or the 'Baianos' versus the 'Paulistas' - in order to emphatically refute this division later. Guimarães discusses and seeks to contest the widespread notion that the UNESCO studies conducted in the Northeast of the country by the 'Baiana' school had preserved Freyre's ideas of 'racial democracy,' while the studies of the Southeast by the 'Paulista' school had arrived at a distinct diagnosis, finally demonstrating the existence of racism and racial discrimination.

In his opinion, not only does a generational divide not exist, but also most scholars, save for some Brazilianists, irrespective of their generation or region, distanced themselves from the comparativist and contrastive paradigm inherited from Freyre to the extent that they elaborated a specifically Brazilian problematics and helped construct a Brazilian research agenda on the racial question. 
Guimarães observes that the consensus surrounding the existence of racial prejudice in Brazil was much greater than is customarily supposed and also that agreement grew regarding the mythic nature of the idea of racial democracy. Still according to his reading, regional differences were not used to negate the applicability of the more general conclusions on racial prejudice in the country.

A notable difference can be discerned here between the evaluation of the UNESCO project made by Guimarães and the one made by Peter Wade, for whom these studies remained attached to the Freyrean paradigm. Guimarães (I999a) differs from the authors analysed earlier since he undertakes an extremely careful exegesis of the literature on race relations in Brazil, dwelling on both the Brazilianists and the Brazilian authors. Furthermore, unlike Wade, he recognizes the impact of the absorption of theories and methods derived from United States academia, but does not presume an automatic and unmediated adherence to concepts like 'assimilation,' to theories of racial prejudice and to the structural functionalism of Robert Park.

Additionally, a strong contrast exists between his form of synthesizing empirical, theoretical and methodological movements within the field of race relations in Brazil and the procedure of another author analysed here, the sociologist Edward Telles. While the latter separates the literature into two distinct generations of studies, Guimarães tends to minimize both generational and regional differences. His bibliographic survey seeks to show that the literature on race relations in Brazil is guided by specifically Brazilian theoretical and methodological concerns, culminating in a view that distances itself from the US focus on the cultural assimilation and integration of the black population into democracy.

Guimarães (1999a) focuses on research conducted between the I950s and 70s, initiated by the UNESCO studies, and emphasizes how the authors from this phase gradually distanced themselves from the legacies of Gilberto Freyre and Donald Pierson, according to whom Brazil had little or no racial prejudice. It is worth remembering that a considerable portion of the sociological research produced between I 940 s and 6os in the United States utilized the theoretical framework developed by the Chicago School. As Michel Omi and Howard Winant (I994) emphasize, this model - widely adopted at the time - presumed that ethnic contact situations involved a succession of stages: conflict, assimilation and finally accommodation. In Guimarães's view, though, while the authors concerned with thinking about Brazil's reality, generally speaking, did indeed draw support from the community studies of the Chicago School, they innovated in their interpretation of the data on Brazilian society, specifically in their ways of conceiving the formation and nature of racial groups, discussing whether they were status communities or classes without communality.

From among the innovations identified by Guimarães (1999a), we can list some of the most significant. Guimarães highlights the way in which Thales 
de Azevedo changed his reading of the racial situation in Brazil, coming to understand it as a country that combined both a class society and an estatebased (caste) order within which status communities were constituted on the basis of colour and family origin. This movement permitted him to move away from the idea of a 'multiracial class society' elaborated by Donald Pierson, for whom individual capability prevailed over ethnic origin as the determinant factor in the potential for social ascension in Brazil. With this, Azevedo admitted that colour and social origin in Brazil constructed prestige groups, or social castes, between which the opportunities and chances for social mobility were differentially distributed. Also prominent in Guimarães's review is the work of Oracy Nogueira. This is firmly located in the field of the theory of racial prejudice and affirms the specificity of Brazilian racial prejudice compared to the kind encountered in the United States. In effect, Guimarães correctly points out that Nogueira broke with the binarism between race and class, which until then had oriented the studies in Brazil, in order to introduce an idea similar to concepts fairly well-known today in the field of race relations, such as the ideas of 'chromatism,' 'colourism' or 'pigmentocracy' (Daflon, 2017).

According to Guimarães (I999a), however, the true exponent of this entire literature is Florestan Fernandes, who he describes as a pioneer in the form of thinking about the singularity of race relations in Brazil. According to the author, one of Fernandes's innovations was to bring the dynamic of racial prejudice into the present, interpreting it as an attempt by the dominant oligarchies to safeguard their inherited privileges and collaborate to maintain an incomplete and particularist bourgeois order endowed with traditional traits. Another novelty was the move away from the theoretical framework of assimilation and integration of the black population into democracy, a dominant preoccupation in the United States, as well as the introduction of the debate on race into a specifically Brazilian political agenda. According to Guimarães (I999a), Florestan's work had the merit of reconciling the concerns of black social movements with social equality and the concerns of nationalists with the country's development, articulating class and race in a structural and original form.

\section{Brazil and the United States}

All the movements detected in the field of race relations in Brazil are, for Guimarães, associated with changes not only in academia itself but also in the western anti-racist agenda. In Racismo e antirracismo no Brasil, Guimarães (I 999b) revisits the tradition of comparing Brazil and the United States from an internalist and externalist perspective in order to elaborate the reasons why the similarities between the two countries passed unnoticed for a long time. These reasons can be summarized as follows: (I) the emphasis of the political program of western anti-racism on the legal and formal status of citizenship, rather than its factual, practical and substantive exercise, made it difficult to place Brazil - a 
country that after abolition had not established an explicitly racist legislation nor formal barriers to the mobility of the black population - in the list of nations marked by racial exclusion and discrimination; (2) the interpretation of the phenomenon of racism via the individualist reading of the notion of 'racial prejudice,' which refers to individual attitudes and manifestations of aversion and antipathy, worked to render invisible the structural dimension of Brazilian racism; (3) the definition of 'race' present in the American context, related to notions of blood and ancestry and more rigid conceptions of heredity, made it difficult to incorporate the mode of racial classification practiced in Brazil around notions of 'colour' in a model of racialism and racism - in this sense, the problematization of racial signifiers and the perception of their fluctuating nature were essential to comprehending Brazil as a racially discriminatory and unequal country; (4) in addition to the innovations introduced into the field of studies of race relations already mentioned here, these changes were enabled by the end of legalized racial segregation in the United States as a result of the civil rights movement. Following the removal of a juridical and legal problematic, studies in the United States itself began to focus on the more subtle mechanisms producing racial inequalities. As Brazilian and American racisms became increasingly alike, the black and feminist movements became more vocalized, making evident the processes of naturalization and social justification of hierarchies, as well as the relations between gender and race (Guimarães, I999b).

In effect, the abolition of the racial segregation laws in the United States in the I 960 s nourished the idea that racism in the country had been overcome and that public policies like affirmative action would be unnecessary, given that black and white individuals enjoyed equal citizenship rights. For Eduardo Bonilla-Silva (2006), this form of denying racial prejudice and discrimination in the United States can be called 'colour-blind racism,' something that would operate in similar form to the myth of racial democracy in Brazil. Moreover, therefore, while 'colour-blind racism' and the myth of 'racial democracy' present similarities in the form in which they express particular understandings of race relations, today it is also possible to encounter parallels in the form in which the two countries racially classify their populations.

\section{SUMMARY}

In their reading of the historiography on race, the historian George Fredrickson emphasized how the historical interpretation of race relations in Brazil shifted from a culturalist paradigm, which aimed to encounter 'patterns' of race relations in the earlier slavery regime, to an institutionalist and contemporary approach, focused on the post-abolition period and that seeks to combine the State, the economy and sociocultural identities in a single approach. Fredrickson stressed in particular the importance of the gradual shift from a perspective of contrast between Brazil and the United States to a comparative perspective, able to recognize not only differ- 
ences but also similarities between Brazil, the United States and other cases of societies that went through the historical experience of slavery and colonization.

Peter Wade, for his part, organized the Brazilian literature in accordance with the impact and influence of different theoretical currents - structural functionalism, the Marxist-structural paradigm and, finally post-structuralist and postmodern approaches to race. The form in which Wade organizes this bibliography is interesting due to its foregrounding of the way in which the subfield of race relations connects to the broader field of the social sciences and social theory. In a more synthetic work, Edward Telles, for his part, described two 'generations' of studies on race relations in Brazil, which according to his argument had 'looked' to different dimensions of race relations, apparently without managing to connect them. Despite producing a certain simplification, Telles called attention to an important lacuna in the more contemporary literature, one that also marked the first generation of studies: the need for greater articulation between the dimension of socioeconomic stratification and the investigation of forms of everyday sociability between black, brown and white populations in Brazil.

Finally, among the authors highlighted, it was Antonio Sérgio Guimarães who wrote the most nuanced history of the interpretations of race relations in the country, producing an exhaustive work of exegesis of the texts and seeking to demonstrate how the authors acquired explanatory power as they moved away from the American problematics and gained intellectual autonomy, constructing specific categories of interpretation and social analysis. His form of organizing the bibliography is particularly interesting since it associates an internalist reading of science, that is, related to its internal interpretative movements, with an externalist perspective, attentive to the way in which social and political changes in Brazil and the United States impacted the respective fields of race relations.

\section{FINAL CONSIDERATIONS}

The summary of the bibliography examined in this article points to the diverse historical changes and innovations introduced into the field of studies of race relations over time. I now seek to indicate and enumerate some of the insights obtained from the present exercise. Firstly, we can note the importance of the change in the comparative and historical analysis, which moves away from a culturalist perspective, the major attempts at syntheses and stabilizations, in order to assume a dynamic and historicized vision of race and racism. Since race relations are mutable in time and space, the search for a cumulative and linear history, involving 'remote origins' and supposed links between the distant past and the present must be viewed with suspicion. The logic of 'contrast' and opposition, which for a long time guided research on Brazil and the United States, for its part, has given way to the study not only of their differences but also their similarities and affinities.

It seems opportune, therefore, to re-examine the idea long gestated in Brazilian social thought that race relations in Brazil were 'singular,' 'excep- 
tional' and, therefore, incommensurable in relation to other national contexts. Clearly Brazil has specificities, but the idea of 'exceptionality' was erected for too long as a barrier against its comparison with other nations. Though varying substantially between countries, the basic elements of colonization, slavery, whitening, miscegenation and multiculturalism are present throughout Latin America. There is a need, therefore, to explore the possibilities for comparison between different regional contexts (Telles, 20I4; Wade, 20I4).

To this trend we can also add the importance of rejecting the 'methodological nationalism' and the 'state-centrism' of some analyses, which fail to inscribe the internal dynamics of Brazil within a global ethnic-racial field or an international politics of development. Along these lines, it is interesting to note the recent expansion of studies on race relations to Latin America - construed not as a homogenous block, but within regional tendencies dictated by the history of development and the region's global insertion.

The work of Mara Loveman (2014) on Latin America provides a prime example. Her choice of this region as an object of study is not justified by any presumed homogeneity between its countries, but by the way in which Latin American nations have experienced the same kind impacts during the construction of their national States in the context of an international system that impressed specific regional tendencies, such as the ideologies of miscegenation and whitening. Tianna Paschel (2016) also pursues comparative work, in this case between the black movements in Brazil and Colombia, which reveals the States as important actors, but while ensuring to include in the analysis regional trends and recognizing the existence and impacts of a global ethnicracial field. In sum, both these authors tend to assume that national territorial boundaries do not produce a 'natural' delimitation of social relations, although the power of nation States should not be overlooked.

A closer exploration of internal divisions may also be productive, including subnational analyses that allow a re-examination of premises of homogeneity between different states or regions of the country. The researcher Kim Butler (I998), for example, worked on the post-abolition era in São Paulo and Salvador, exploring the impacts of European immigration on black identities and associativism in São Paulo, encountering significant regional differences.

It is also worth stressing that the literature has repeatedly identified the need to produce more microsociological research, which allow to decipher the everyday operations of racism and racial discrimination in Brazil. The research conducted since the mid-I970s in Brazil has mostly been concerned with registering racial inequalities and refining methods for the statistical measurement of racial discrimination. Hence it is worth emphasizing the difference between statistical inference - which allows to detect one or more characteristics in a population, as well as to register inequalities and distinct patterns of social mobility, and even estimate discrimination through statistical models - and logical 
or causal inference, which enables to produce explanatory schemas concerning the connection between two or more of these characteristics (Small, 2009). Today there is an abundant Brazilian literature on the quantitative and structural dimension of inequality and discrimination. However, more studies on perception, ethnographies, surveys of attitudes, laboratory and field experiments that enable the causal dimensions of inequalities to be explored are needed.

A good general orientation also involves taking the boundaries between groups as problematic and not assuming that 'races' exist as socially determined and cohesive groups, whose identities are mechanically recognized by the State. The emphasis shifts, therefore, from research on the supposed 'substance' of ethnic or racial groups to the relational analysis of the construction of boundaries and collective identities (Lamont \& Molnár, 2002). It is worth recalling that, as Guimarães (I999a) warned, essentialized visions functioned for a long time as an obstacle to the comprehension of the singularities of the Brazilian - and Latin American - case. He also emphasized that the construction of a research agenda on racism and racial discrimination in Brazil derived from a strong movement of anti-essentialism in the field of research on race relations.

To conclude, it is important to bring to the research on race its complex interaction with other axes like gender, class and sexuality. The 'intersectional' approach proposes that forms of oppression possess affinities, parallels and mechanisms of mutual reinforcement. This means that while, on one hand, the categories of race, gender, sexuality, national origin and so on are analytically separate, empirically they find themselves in a process of interaction and codetermination (Hill Collins, 20I5). It should be pointed out, however, that the same exhortation that races should not be taken as stable, preestablished and founding entities is applicable to axes like gender, class and the like. Taking these categories as static and non-problematic implies abdicating an essential part of the sociological research, namely to historicize categories and interrogate social relations without assuming a priori that they represent fixed positions. As Danièle Kergoat (2010) advises, depending on how social relations are configured, gender (or class, or race) will comprise the relevant and unifying empirical element of a particular dimension of inequalities. Recognizing the mutable and dynamic nature of social relations and their susceptibility to the movements of sociology itself, we should observe too that the field is in permanent movement. Given this observation, it is essential to reflect on the possibilities for expanding the research on race relations into areas that dialogue with the contemporary world and the questions of the present, without leaving out the rich academic production analysed here. 
Veronica Toste Daflon is a postdoctoral researcher on the Postgraduate Program in Sociology and Anthropology (PPGSA-UFRJ) and a researcher for the Interdisciplinary Nucleus of Studies on Inequality (NIED) and the Nucleus of Sexuality and Gender Studies (NESEG). She holds a PhD in Sociology from IESP-UERJ and an MA in Sociology from IUPERJ. She has published the books Tão longe, tão perto: identidades, discriminação e estereótipos de pretos e pardos no Brasil and Guia multidisciplinar da ação afirmativa: Brasil, Índia $e$ África do Sul. Her main interests are gender, race and public policies. 


\section{BIBLIOGRAPHY}

Arruti, José Maurício. (2006). Mocambo: antropologia e história no processo de formação quilombola. Bauru: Edusc.

Bethencourt, Francisco. (2013). Racisms: from de Crusades to the Twentieth Century. Princeton: Princeton/Oxford University Press.

Bonilla-Silva, Eduardo. (2006). Racism without racists: colorblind racism and the persistence of racial inequality in the United States. Plymouth: Rowman \& Littlefield Publishers.

Boxer, Charles. (2002). O império marítimo português I4I5-I 825. São Paulo: Companhia das Letras.

Butler, Kim. (1998). Freedoms given, freedoms won: Afro-Brazilians in post-abolition São Paulo and Salvador. London: Rutgers University Press.

Chalhoub, Sidney \& Pinto, Flavia Magalhães (eds.). (2016). Pensadores negros-pensadoras negras do século XIX e XX. Belo Horizonte: Traço Fino.

Cooper, Frederick. (1996). Race, ideology, and the perils of comparative history. The American historical review, I0I/4, p. II22-II38.

Costa Pinto, João Alberto da. (2009). Gilberto Freyre e a intelligentsia salazarista em defesa do Império Colonial Português (I95I-I974). História, 28/I, p. 445-482.

Daflon, Veronica T. (2017). Tão longe, tão perto: identidade, discriminação e estereótipos de pretos e pardos no Brasil. Rio de Janeiro: MauadX.

Daniel, G. Reginald. (2006). Race and multiraciality in Brazil and the United States: converging paths? University Park, PA: Penn State University Press.

Degler, Carl. (I97I). Neither black nor white: slavery and race relations in Brazil and the United States. New York: MacMillan. Fernandes, Florestan (1972). O negro no mundo dos brancos. São Paulo: Difusão Europeia do Livro.

Fernandes, Florestan. (1965). A integração do negro na sociedade de classes. São Paulo: Edusp.

Fredrickson, George M. (200I). Race and racism in historical perspective: comparing the United States, South Africa, and Brazil. In: Hamilton, Charles V. et al. (eds.). Beyond rac- 
ism: race and inequality in Brazil, South Africa and the United States. Boulder, CO: Lynne Rienner Publishers, p. I-28.

French, Jan H. (2009). Legalizing identities: becoming black or indian in Brazil's northeast. Chapel Hill: University of North Carolina.

Guimarães, Antonio Sérgio Alfredo. (2012). Preconceito racial: modos, temas e tempos. São Paulo: Cortez.

Guimarães, Antonio Sérgio Alfredo. (I999a). Baianos e paulistas: duas "escolas" de relações raciais? Tempo Social, I I/ I, p. 75-95.

Guimarães, Antonio Sérgio Alfredo. (I999b). Racismo e antirracismo no Brasil. São Paulo: Editora 34.

Hanchard, Michael \& Chun, Erin Aeran. (2004), From race relations to comparative racial politics. Du Bois Review, I/2, p. 319-343.

Hill Collins, Patricia. (20I5). Em direção a uma nova visão: raça, classe e gênero como categorias de análise e conexão. Cadernos Sempreviva, São Paulo, I6/29, p. 13-42.

Kergoat, Danièle. (20Io). Dinâmica e consubstancialidade das relações sociais. Novos Estudos CEBRAP, 86, p. 93I03.

Lamont, Michèle \& Molnár, Virág. (2002). The study of boundaries in the social sciences. Annual Review of Sociology, 28, p. I67-I95.

Loveman, Mara. (20I4). National colors: racial classification and the state in Latin America. New York: Oxford University Press. Maio, Marcos Chor. (2010). Introdução: a contribuição de Virgínia Leone Bicudo aos estudos sobre as relações raciais no Brasil. In: Bicudo, Virgínia Leone. Atitudes raciais de pretos e mulatos em São Paulo. São Paulo: Editora Sociologia e Política. Marx, Anthony. (1998). Making race and nation: a comparison of South Africa, the United States, and Brazil. Cambridge: Cambridge University Press.

Munanga, Kabengele. (I999). Rediscutindo a mestiçagem no Brasil: identidade nacional versus identidade negra. Petrópolis: Vozes.

Omi, Michael \& Winant, Howard. (1994). Racial formation in the United States: from the Ig6os to the I99os. New York: Routledge. 
Ortiz, Renato. (1985). Cultura brasileira \& identidade nacional. São Paulo: Brasiliense.

Paschel, Tianna. (2016). Becoming black political subjects: movements and ethno-racial rights in Colombia and Brazil. Princeton: Princeton University Press.

Silva, Nelson do Valle. (I995). Morenidade: modos de usar. Estudos Afro-Asiáticos, 30, p. 79-95.

Silva, Nelson do Valle; Hasenbalg, Carlos \& Lima, Marcia. (I999). Cor e estratificação social. Rio de Janeiro: Contra Capa. Skidmore, Thomas E. (1976). Preto no branco: raça e nacionalidade no pensamento brasileiro. Rio de Janeiro: Paz e Terra.

Small, Mario. (2009). How many cases do I need? On science and the logic of case selection in field-based research. Etnography, Io, p. 5-38.

Sovik, Liv. (2009). Aqui ninguém é branco. Rio de Janeiro: Aeroplano.

Tannembaum, Frank. (1946). Slave and citizen: the negro in the Americas. New York: Vintage Books.

Telles, Edward. (20I4). Pigmentocracies: ethnicity, race and color in Latin America. Chapel Hill: The University of North Carolina Press.

Telles, Edward. (2004). Race in another America: the significance of skin color in Brazil. Princeton: Princeton University Press.

Theodoro, Mario. (2008). Desigualdade racial e mobilidade social no Brasil: um balanço das teorias. In: Theodoro, Mário et al. As políticas públicas e a desigualdade racial no Brasil I 20 anos após a Abolição. Brasília: Ipea, p. 65-96.

Wade, Peter. (20I4). Ciência e política na produção das diferenças: entrevista com Peter Wade. Entrevista a Flávia Rios e Catalina González-Zambrano. Revista de Antropologia, 57/2, p. 485-505.

Wade, Peter. (2002). Race, nature and culture: an anthropological perspective. Sterling: Pluto Press.

Wade, Peter. (1997). Race and ethnicity in Latin America. Chicago: Pluto Press.

Williamson, Joel. (1984). New people: miscegenation and mulattoes in the United States. New York: New York University Press. 


\section{Palavras-chave \\ Sociologia das relações raciais; relações raciais; \\ raça; \\ racismo; teoria sociológica.}

Keywords

Sociology of race relations; race relations;

race;

racism; sociological theory.

\section{FORMAS DE SISTEMATIZAÇÃO DAS SOCIOLOGIAS DAS RELAÇÕES RACIAIS NO BRASIL}

Resumo

Ao longo da sua formação como pesquisadores e docentes, os acadêmicos que trabalham com relações raciais assimilam uma história canônica da produção desse campo. Com algumas variações, essa produção é habitualmente organizada em torno de uma narrativa que se inicia com a recepção do racismo científico no Brasil, passa em seguida para a formulação da abordagem culturalista e da tese da "democracia racial" e segue para as rupturas que finalmente conduziram ao reconhecimento e investigação de padrões de racismo e discriminação no Brasil. Este artigo apresenta uma síntese dessa história para em seguida interrogá-la sob diferentes ângulos e perspectivas. Para tal, apoia-se em intérpretes da sociologia e historiografia das relações raciais visando apontar como determinadas reorientações teóricas e metodológicas no campo e mudanças sociais de âmbito nacional e internacional estão conectadas a diferentes interrogações lançadas sobre o fenômeno do racismo no Brasil.

\section{FORMS OF SYSTEMIZATION OF THE SOCIOLOGY OF RACE RELATIONS IN BRAZIL}

\section{Abstract}

Throughout their training as researchers and teachers, academics working with race relations assimilate a canonical history of the production in the field. With some variations, this production is usually organized around a narrative that begins with the reception of scientific racism in Brazil, then goes on to formulate the culturalist approach and the thesis of 'racial democracy' and, finally, mentions the ruptures that led to the recognition and investigation of patterns of racism and discrimination in Brazil. This article presents a synthesis of this history and then interrogates it from different angles and perspectives. To achieve this objective, it turns to interpreters of the sociology and historiography of race relations to reveal how certain theoretical and methodological reorientations in the field, along with national and international social changes, are connected to the different questions raised with regard to the phenomenon of racism in Brazil. 